УДК 81'06'37'42: 811.111
DOІ 10.35433/philology.1(89).2019.140-145

Л. М. Чумак,

кандидат філологічних наук, старший викладач

(Житомирський державний університет імені Івана Франка)

liudmylachumak@gmail.com

ORCID: 0000-0001-6631-3403

І. Е. Сніховська,

кандидат філологічних наук, доцент

(Житомирський державний університет імені Івана Франка)

irena29@gmail.com

ORCID: 0000-0001-6775-274X

\title{
СТРУКТУРНО-СЕМАНТИЧНІ ТА ФУНКЩІОНАЛЬНІ ОСОБЛИВОСТІ ЛЕКСИЧНИХ IННОВАЦЙ, ЩО ВИРАЖАЮТЬ ПОНЯТТЯ "GENERATION" В СУЧАСНОМУ АНГЛОМОВНОМУ МЕДІЙНОМУ ДИСКУРСІ
}

Стаття присвячена аналізу будови, значення та функціональних характеристик лексичних одиниць, щуо вживаються в медійному дискурсі на позначення понять, пов'язаних із належністю людей до різних демографічних поколінь сучасного англомовного суспільства. Фактичною базою слугують сучасні лексикографічні джерела та фрагменти медійного дискурсу з он-лайн версій англомовних газет та журналів. Вираження поняття "gепегаtion" лексичними засобами актуалізують репрезентаиї таких референтів, як: люди за віковою, груповою належністю, статусом, за певною характерною ознакою,

групи однодумиів тощчо.

Ключові слова: нові лексеми, соціально-демографічні групи, медійний дискурс.

Постановка проблеми. Дослідження лексичних інновацій, що репрезентують різні демографічні покоління, проводиться на аналізі структури, семантики та функціонування мовних одиниць в сучасному англомовному медійному дискурсі. Виявлення прагматичної значущості нових слів, які використовуються на позначення людей певного віку, грунтується на визначенні мети використання цієї групи лексики в англомовному медійному дискурсі. Вивчення функціональних особливостей вживання лексичних одиниць на позначення характерних ознак відповідної соціально-демографічної групи та факторів, що формують соціальну сферу сучасності, дозволяє отримати більш доступне та інформативне уявлення про одиниці мови як засіб вираження та передачі найповнішої інформації. Актуальність обраної теми передбачає аналіз мовних феноменів, що корелюються "людським фактором", оскільки $€$ складовою об'єктивації феноменів дійсності.

Формулювання мети і завдань статті. Мета статті полягає у дослідженні формальної, семантичної структури лексичних одиниць, що виражають поняття належності до різних демографічних поколінь в англомовному суспільстві; особливостей функціонування цих новотворів у сучасному англомовному медійному дискурсі. Для досягнення поставленої мети дослідження висуваються такі завдання: 1) відбір лексичного матеріалу з сучасного англомовного медійного дискурсу; 2) аналіз структури та значень виокремлених лексем; 3) виявлення функціональної значущості аналізованих лексичних одиниць.

Аналіз останніх досліджень і публікацій. Творення лексичних інновацій $є$ втіленням у мовній практиці розвитку лексичного складу мови з одного боку, а 3 іншого - функції класифікаційнопізнавальної діяльності людини [1:3]. Нова лексична одиниця виступає як результат узагальненорозумової діяльності людини [2: 7]. У результаті актуалізації функціональних можливостей одиниць мови, при незмінності своєї форми, з'являються нові, нетипові для них раніше категоріальні, синтаксичні та прагматичні характеристики [3:7]. Інноваційні процеси у лексиці досліджувались у вітчизняному мовознавстві як на матеріалі лексикографічних джерел англійської, української та російської мов (В. А. Голець, О. А. Стишов, Л. В. Васильєва, І. П. Гусак, А. О. Худолій), так і в різновидах дискурсу (Н. І. Андрейчук, І. С. Короленко, Л. В. Рацибурська, Л. В. Солощук, Ю. О. Шевлякова).

Виклад основного матеріалу. Комунікативний ресурс трансформованих мовних одиниць розвивається за рахунок двох абсолютно протилежних, об'єктивних та взаємопов'язаних тенденцій інтеграції та диференціації одиниць мовної системи, які спричиняють процес функціонування лексики, що, власне, й призводить до появи мовних одиниць [4: 7].

Процеси, що стосуються інтеграції (виокремлення спільних ознак, функцій) елементів мовної системи у вигляді лексичних одиниць, з одного боку, та поділу (диференціації) лексичних одиниць на окремі елементи, з іншого, є підгрунтям функціонування лексики, та можливістю активного використання в актах подальшої деривації. Реструктуровані номінативні знаки лексичного рівня розглядаються як особливий прошарок між лексичним та морфологічним рівнями. Водночас сам процес реструктуризації 
лексичних одиниць призводить до реформування, удосконалення та комбінування засобів та способів творення лексичних інновацій.

Такий прояв дуалізму елементів сучасної англійської мови спостерігається, з одного боку, у загальній тенденції до економії мовної енергії, прагненні мовців до раціоналізації, прагматизму, що веде до спрощення структури лексичних одиниць. А з іншого боку є всі підстави говорити про розвиток мовних ресурсів шляхом актуалізації різних способів перетворення структури (інтеграції, диференціації, трансформації, транспозиції, модифікації, перекатегоризації, аналогії) вже існуючих у мові одиниць номінації.

У плані дослідження структури та семантичного наповнення лексичних одиниць, що позначають розподіл сучасного англомовного населення за віком, було обрано лексеми, що виражають та співвідносяться з поняттям "generation". Лексико-семантичний аналіз виокремлених лексем проведено на матеріалі англомовних лексикографічних джерел. Лінгвопрагматичний аналіз вживання досліджуваних лексичних інновацій здійснено на матеріалі сучасного англомовного медійного дискурсу 3 on-line версій газет і журналів.

Відбір лексичних одиниць, що використовуються для вираження поняття "generation" було здійснено методом суцільної вибірки із сучасних англомовних текстових фрагментів медійного дискурсу. Вибір саме таких текстових фрагментів в онлайн-версіях як матеріалу дослідження пояснюється насиченістю мови сучасних англомовних медіатекстів новими лексичними інноваціями, які позначають різні події у житті сучасної людини. Вивчення лексичних інновацій у медійному дискурсі, що грунтується на тематичному підході, дає змогу простежити, як нові слова у медіатекстах групуються за відповідною тематикою, фокусуючи увагу читача на найважливіших у той чи інший момент суспільно-громадських темах [5: 75].

У цьому зв'язку в якості ключового текстового фрагмента із сучасного англомовного медійного дискурсу було обрано повідомлення, у яких поняття "generation" виступає як найбільш узагальнююче за своєю семантикою - "а group of individuals, most of whom are the same approximate age, having similar ideas, problems, attitudes, etc." [6]: Americans like to give names to generations. We call those who lived through World War II, the "Greatest Generation"; those who came of age reading the beatnik poets of the 1950s, the "Beat Generation"; those for whom the reckless investors in the 1970s were role models, the "Me Generation"; and those who grew up disaffected and cynical at the end of the 20th Century, "Generation X." [www.voanews.com].

Лексичні одиниці Greatest Generation, Beat Generation, Me Generation, Generation $X$, що супроводжуються у аналізованому фрагменті хронологічними датами (World War II, the 1950s, the 1970s, the 20th Century) є складовими позначення поняття "generation", що унаочнює динамічний розвиток та ритм зміни поколінь. При цьому автор медіатекстового фрагменту деталізує кожну соціальнодемографічну групу шляхом вживання як препозитивних, так і постпозитивних означень (those who lived through; those who came of age reading the beatnik poets; those for whom the reckless investors ... were role models; those who grew up disaffected and cynical).

Прийом деталізації інформації про явища дійсності за допомогою акцентування кількісних, вікових властивостей учасників подій репрезентує і лексична інновація Millennials: While 45 percent of Baby Boomers (ages 49-67) say they worry "often" about privacy, younger generations (Millennials, ages 18-30) are more likely to include the Web in their definition of privacy and have taken proactive steps to protect themselves, such as creating content to improve Google search results or using multiple email addresses. (PR Newswire, April 23, 2013). Аналізована лексема Millennials, словникова дефініція якої визначається як "born in the 1890s, 1990s, or early 2000s" [7], демонструє градацію віку дітей покоління "бебі-буму" на часовій шкалі 3 чіткою віковою протяжністю. При цьому в аналізованому повідомленні за допомогою мовних зворотів more likely та such as актуалізуються кваліфікативні ознаки учасників двох вікових груп.

Лексема Millennials є випадком утворення нових лексичних одиниць, пов'язаних із дією механізму компресії, що супроводжується усіченням синтаксичного компонента та представленого моделлю, утвореною в результаті еліпса іменника-ядра, або елімінації ядра, при якому модифікатор синтезує власне значення зі значенням ядра. Основною передумовою творення субстантиванта є семантичний зв'язок прикметника з цілим вихідним словосполученням [5: 128].

Іншим випадком позначення демографічного покоління, вживаному в англомовному медійному дискурсі, є лексема Xennials, утворена внаслідок поєднання другого компонента ініціального скорочення Generation X та еліптизованої інновації Millennials. Американська компанія, видавець довідників і лексичних словників Merriam-Webster у 2017 році виокремила інновацію Xennials у розділі "Words We're Watching". Укладачі словника зазначили, що ця лексема вперше була використана письменницею Сарою Станкорб у журналі "GOOD" у вересні 2014 року при позначенні певної групи людей як окремого покоління (народжених у період кінця 1970-х та початку 1980-х), життя яких відзначається відчуттям їх перебування у середині двох епох: Between Generation $X$ and the Millennials, there's a group of people currently in their late 20 s and early 30 s who don't identify with either label. We call them the Xennials - a 
micro-generation that serves as a bridge between the disaffection of Gen $X$ and the blithe optimism of Millennials. (GOOD Magazine, September 25, 2014).

Залучення зазначеної лексеми у медійні повідомлення виявляє апеляцію до потреб у належності, як прояву стратегії апеляції до потреб, що виражає входження людей до різних соціальних утворень - сім'ї, клану, групи, колективу, суспільного класу тощо [8: 87]: Xennials aren't especially pessimistic, but they aren't as optimistic and confident as Millennials tend to be. A 2016 report found that Millennials were more optimistic about the future than previous generations of young people. (Business Insider, April 25, 2018). Належність до групи демографічного покоління ксенніалів активізується позначенням категоріальних ознак іменника (Xennials), що репрезентує характеристики аналізованого референта шляхом використання описових означень (especially pessimistic, optimistic, confident), та який співвідноситься 3 іншою демографічною спільнотою (Millennials).

Уживання лексичної одиниці Xennials у медійному дискурсі також обумовлено потребою позначення аспектів нових явищ, пов'язаних із життям представників цього покоління, що відповідають базовим потребам їх існування. Так, дослідники-журналісти зазначають, що саме покоління ксенніалів найбільше зазнало спаду ділової активності у період Світової фінансово-економічної кризи (2007-2008 рр.) через заборгованість по виплаті студентських кредитів, втратою робочих місць: Interestingly, some research suggests that xennials may have been hit hardest by the recession because of a combination of student-loan debt, job losses, and other factors (Business Insider, April 25, 2018).

У наступному медійному повідомленні використання лексичної одиниці Xennials пов'язується 3 позначенням учасників подій та їхньої діяльності, що актуалізують тактику апеляції до суспільної та національної безпеки: Another shared experienced of Xennials is their entry into the workforce not long before the market crash of 2008. When younger millennials began to graduate after the recession took hold, they found a blighted jobs cape. Gen Xers, who were established in their careers, lost livelihoods from layoffs, stock dives and mortgage foreclosures. But Xennials were still new in the workforce, and were secure in low-paying jobs that survived cuts and turned into careers. They hadn't had time to invest, and had little to lose. (Star Tribune, December 2, 2017).

Суспільна безпека у аналізованому повідомленні відображена позначенням складного соціального явища, у якому реалізуються суспільні цінності (established in their careers), інтереси (low-paying jobs that survived cuts and turned into careers), потреби (entry into the workforce) "ксенніалів" у порівнянні 3 "мілленіалами". Контрастування між двома поколіннями (millennials, Xennials) виявляється у вказівці на їх несхожість шляхом деталізації джерела та цілі протидії, яка сигналізує про боротьбу різних суспільних груп [9: 278] (millennials began to graduate after the recession took hold, they found a blighted jobs cape. But Xennials were still new in the workforce). Апеляція до суспільної безпеки у вищеподаному повідомленні розглядається як складова національної безпеки, що, у свою чергу, реалізується у шляхом вживання словосполучення the market crash of 2008, яке узагальнює загрозу безпеки розвитку суспільства. Фінансова криза 2008 року в США розглядається на рівні національної проблеми, яка у медійному повідомленні передається лексемою recession та відображає створення перешкод потребам як індивідуумів, так і суспільства загалом.

Реалізацією позначення потреби в належності до суспільно-демографічної групи демонструє також i лексична інновація Sandwich Generation - "the group of people who have old parents as well as young children, so they have to take care both of their parents and of their children" [7]. Люди віком від 40 до 50 років репрезентують покоління, яке надає підтримку, у тому числі й фінансову, як своїм літнього віку батькам, так і дітям на утриманні: As America's population grows older, so do the demands on workers with aging parents. Children of baby boomers are now in their 30s, 40s and 50s, their prime earning years. They may have gained leadership positions in their workplaces. And, they may be part of what the CDC calls the Sandwich Generation, those who are simultaneousously caring for an elderly parent and their own children under age 18. (Forbes, January 24, 2019). За повідомленням американського видавця довідників та лексичних словників Мерріам-Вебстер у 2006 році ця лексична одиниця офіційно ввійшла до лексичного складу сучасної англійської мови.

У сучасному англомовному медійному дискурсі на позначення людей за віковою належністю функціонує й новотвір snowflakes (snowflake generation) - "an insulting way of referring to someone who is considered by some people to be too easily upset and offended" [10], утворення якого подібно до лексеми Millennials, пов'язується 3 результатом еліпсу ядра. Про активність використання в англомовному медійному дискурсі лексеми snowflake, що позначає покоління, період дорослішання якого припало на початок XXI століття, свідчить номінація "слово року" за версією газети "Financial Times" та його включення в десятку слів 2016 року словником Коллінза. У подальшому ця лексична інновація стала настільки часто вживаною, що у січні 2018 року іiі було додано до одного з найвідоміших академічних словників англійської мови - Oxford English Dictionary.

Випадок використання лексичної одиниці snowflakes у наступному повідомленні вживається як демонстрація ознаки "видової деталізації, що позначає належність учасників до певних груп людей" 
[9: 268]: Until then, I'd bought into the current myth that today's younger people were somehow degenerating into 'snowflakes' - that they're a hopeless lot, popularly defined as selfie-obsessed, social media junkies, all vain, spoiled, no gumption, no get-up-and-go, melting at the first sign of difficulty (The Daily Mail, March 18, 2019). Репрезентація контекстуальної ситуації після введення аналізованої лексеми snowflakes відбиває належність індивідуумів до зазначеної соціальної групи, яку автор супроводжує негативно оцінним дієсловом degenerate зі значенням "to become worse in quality" [7].

В аналізованому повідомленні позначення учасників подій активується номінативними одиницями, що іменують ознаки суспільної належності до "покоління сніжинок", зокрема: надмірна переконаність у власній унікальності (selfie-obsessed), добра обізнаність та використання у повсякденному житті різноманітних мультимедійних пристроїв (social media junkies), та все ж, у випадках неспівпадіння особистих сподівань і реальності, виявляється зниження самоконтролю, нездатність добре й швидко приймати рішення (all vain, spoiled, no gumption, no get-up-and-go, melting at the first sign of difficulty).

Характерною ознакою реалізації тактики інформування $\epsilon$ також i застосування послідовних ланцюжкових визначень. Наприклад, у наступному фрагменті медійного дискурсу інформацію про молоде покоління сучасності подано через прийом порівняння: Some people call these Internet do-ityourselfers Generation $\boldsymbol{C}$, for the creative content they put on the Net. Or citizen media, meaning they're average people offering their work to the world. Another name is Generation $\boldsymbol{E}$ for entitled, because these folks feel they have just as much right as established writers or musicians or filmmakers to be heard. (Federal Information \& News Dispatch (Washington, D.C.), May 19, 2004).

В аналізованому уривку порівнюються дві номінативні одиниці - Generation C та Generation E: прийменник for i наступне за ним слово та словосполучення виконують функцію постпозитивного означення (Generation C for the creative content, Generation E for entitled). Підрядний сполучник because вказує на причину зв'язку між суб'єктом та ситуацією (these folks feel they have just as much right as established writers or musicians or filmmakers to be heard).

Словниковий та етимологічний аналіз лексеми "Generation C" визначає цю демографічну групу як "the people who create and publish material such as blogs, podcasts, videos, etc, on the internet" [10], a came ініціальне скорочення C - $є$ еквівалентною заміною початкової літери слова "content". Дефініцію лексеми Generation E виявляємо у фрагменті медійного повідомлення, опублікованого в одній із найвпливовіших газет світу - "The New York Times": I can't keep track of what young people are being called these days after a string of "Generation [ ]" labels. But my vote would be Generation E, for energy and the environment, if initiatives at a host of schools around the United States are any indication. (The New York Times, July 27, 2008).

Нещодавно в англомовному медійному дискурсі з'явились та почали активно функціонувати ще декілька нових лексичних одиниць на позначення наймолодшого демографічного покоління, зокрема лексема: Generation Z - "покоління Z", або "джензери" від словосполучення Gen $Z$ та відповідний синонімічний ряд, що в повній мірі позначає аналізоване поняття: Post-Millennials, Generation M (GenM, the Multitasking Generation), Net Generation (Net Gen), Internet Generation (iGen, Generation I), Gen Tech, Gen Wii ("a term (one of many) for those who are 12-18 years old in 2008" [11]), Digital Natives, Founders, the Homeland Generation, the Pluralist Generation (Plurals), Delta Generation (Deltas), the Centennials. Хоча це покоління ще молоде, автори англомовного медійного дискурсу чітко окреслили серію ідентифікаторів, що відрізняють його від інших та пояснюють позначуване явище. Це покоління цифрового світу, вседоступного Інтернету, без чіткої межі між реальним та віртуальним світом; мультикультурне, оскільки Інтернет спілкування не розмежовує людей за расовою, гендерною, релігійною тощо ознаками; залежне від реклами, швидко інтегроване в цифрове спілкування, проте зацікавлене у власній безпеці та особистому простірі; здатне виконувати декілька завдань, не концентруючись лише на одному предметі, при цьому краще сприймаючи інформацію візуально.

Особливості вираження смислового змісту нових лексем виявляєся через мету їх використання в англомовному медійному дискурсі. Наприклад, лексична інновація Centennials, що позначає нову генерацію - "центенніалів", утворена подібно до еліптизованої лексеми Millennials шляхом опущення одного із членів синтаксичної конструкції (generation), що легко домислюється та відновлюється в контексті [12:171]. У наступному медійному фрагменті увага акцентується на такій визначальній характеристиці позначуваного явища, як стабільність через ставлення центенніалів до світу моди - ім не подобаються одноразові речі, вони купують те, що можна довго носити: Marketing gurus are trying to position this nonlook as a trend in itself: anti-style as a generational instinct. In a recent report called "Meet the Centennials" - another name for Generation Z - the Futures Company, a global marketing consultancy, reported that 47 percent of the youths it surveyed (ages 12 to 17) say they "care a lot about whether their clothes are in style," compared with 65 percent for millennials surveyed in 1999. (The New York Times, September 18, 2015).

В іншому фрагменті медійного дискурсу центенніали зображуються як цілеспрямовані, прагматичні, готові багато працювати та знають, як досягнути успіху: When hiring a centennial, it is advisable to 
consider that they're mainly attracted by projects they're interested in rather than by a sense of belonging towards an organization, and in their thoughts regarding the future they see themselves switching companies four times on average (http://sustainabletalent.acciona.com).

Висновки та перспективи подальшого дослідження проблеми. Отже, англомовне суспільство представлене різними поколіннями, яким прийдеться співіснувати разом ще багато років. Тому медійний дискурс і виконує дуже важливу роль: виражає поняття "generation" лексичними засобами, роз'яснюючи специфіку світосприйняття різних соціальних, вікових груп, визначаючи їх спільні та відмінні ознаки, тим самим пояснюючи позначувані явища лексичними одиницями. Проведений аналіз структури, семантики та функціонування лексичних інновацій, що виражають поняття "generation" в сучасному англомовному медійному дискурсі, відображає дослідження нової лексики 3 погляду структурносемантичного та лінгвопрагматичного аспектів. Перспективою для подальших досліджень вбачаємо в аналізі лексичних інновацій виокремлено тематичної групи у таких типах дискурсу, як новинний та Інтернет-дискурс.

\section{СПИСОК ВИКОРИСТАНИХ ДЖЕРЕЛ ТА ЛІТЕРАТУРИ}

1. Горпинич В. О. Словотворення і словотвір української мови / В. О. Горпинич. - К. : Наукова думка, 1995. $68 \mathrm{c}$.

2. Сакал Т. М. Історико-ономасіологічне та когнітивне дослідження префіксальних неологізмів у англійській мові : автореф. дис. ... канд. філол. наук : 10.02 .04 / Т. М. Сакал. - Львів, 2004. - 20 с.

3. Левицкий А. Э. Явление функциональной переориентации языковых единиц / А. Э. Левицкий // Вісник Київського лінгвістич. ун-ту. - 1999. - № 1. - Т. 2. - С. 48-53.

4. Стишов О. А. Динамічні процеси в лексико-семантичній системі та в словотворі української мови кінця ХХ ст. (на матеріалі мови засобів масової інформації) : автореф. дис. ...д-ра філол. наук 10.02.01/ О. А. Стишов. - К., 2003. -35 с.

5. Чумак Л. М. Лексичні інновації в англомовному медійному дискурсі початку XXI століття : структурний $\mathrm{i}$ лінгвопрагматичний аспекти : дис. ... канд. філол. наук : 10.02.04 / Л. М. Чумак. - Київ, 2018. - 269 с.

6. Dictionary.com [Електронний ресурс]. - Режим доступу : https://www.dictionary.com.

7. Cambridge Advanced Learners Dictionary [Електронний ресурс]. - Режим доступу : http://www.dictionary.cambridge.org.

8. Маслоу А. Г. Мотивация и личность / А. Г. Маслоу. - СПб : Евразия, 1999. - 478 с.

9. Потапенко С. І. Сучасний англомовний медіа-дискурс : лінгвокогнітивний i мотиваційний аспекти : [моногр.] / С. І. Потапенко. - Ніжин : Видавництво НДУ ім. М. Гоголя, 2009. - 391 с.

10. Collins English Dictionary : Complete and Unabridged Edition [Електронний ресурс] : 13th Edition. - Collins, 2018. - 2336 р. [Електронний ресурс]. - Режим доступу : https://www.collinsdictionary.com/dictionary/english.

11. Urban Dictionary [Електронний ресурс]. - Режим доступу : https://www.urbandictionary.com.

12. Українська мова : енциклопедія : 2-ге вид. / редкол. : В. М. Русанівський, О. О. Тараненко, М. П. Зяблюк [та ін.]. - К. : Укр. енцикл. імені М. П. Бажана, 2004. - 824 с.

\section{REFERENCES (TRANSLATED \& TRANSLITERATED)}

1. Horpynych V. O. Slovotvorennia i slovotvir ukrayins'koi movy [Word-Building and Word-Formation of the Ukrainian language] / V. O. Horpynych. - K. : Naukova dumka, 1995. - $68 \mathrm{~s}$.

2. Sakal T. M. Istoryko-onomasiolohichne ta kohnityvne doslidzhennia prefiksal'nykh neolohizmiv u anhliys'kii movi [Historical-Onomasiological and Cognitive Research of Prefixal Neologisms in the English language] : avtoref. dys. ... kand. filol. nauk : 10.02.04 / T. M. Sakal. - Lviv, 2004. - 20 s.

3. Levytskyy A. E. Yavleniye funktsional'noi pereoriientatsii yazykovykh yedinits [The Phenomenon of Functional Reorientation of Language Units] / A. E. Levytskyy // Visnyk Kyivs'koho linhvistych. un-tu [Messenger of Kyiv National Linguistic University]. - 1999. - № 1. - T. 2. - S. 48-53.

4. Styshov O. A. Dynamichni protsesy v leksyko-semantychnii systemi ta v slovotvori ukrains'koi movy kintsia XX st. (na materiali movy zasobiv masovoyi informatsii) : avtoref. dys. ... dokt. filol. nauk : 10.02.01 / O. A. Styshov. - Kyiv, 2003. $-35 \mathrm{~s}$.

5. Chumak L. M. Leksychni innovatsii $\mathrm{v}$ anhlomovnomu mediynomu dyskursi pochatku XXI stolittya: strukturnyi i linhvoprahmatychnyi aspekty [Lexical Innovations in the English Language Media Discourse of the Beginning of the XXI Century: Structural and Linguistic and Pragmatic Aspects : dys. ... kand. filol. nauk : 10.02.04/ L. M. Chumak. - Kyiv, 2018. - 269 s.

6. Dictionary.com [Elektronnyi resurs]. - Rezhym dostupu : https://www.dictionary.com.

7. Cambridge Advanced Learners Dictionary [Elektronnyy resurs]. - Rezhym dostupu : http://www.dictionary.cambridge.org.

8. Maslou A. G. Motivatsiia i lichnost' [Motivation and Personality] / A. G. Maslou. - SPb : Yevraziya, 1999. - $478 \mathrm{~s}$.

9. Potapenko S. I. Suchasnyi anhlomovnyi media-dyskurs: linhvokohnityvnyi i motyvatsiynyi aspekty [Contemporary English-Language Media Discourse : Linguocognitive and Motivational Aspects]: [monohr.]/ S. I. Potapenko. - Nizhyn : Vydavnytstvo NDU im. M. Hoholya, 2009. - 391 s.

10. Collins English Dictionary : Complete and Unabridged Edition [Elektronnyi resurs] : 13th edition. Collins, 2018. 2336 p. - Rezhym dostupu : https://www.collinsdictionary.com/dictionary/english.

11. Urban Dictionary [Elektronnyy resurs]. - Rezhym dostupu : https://www.urbandictionary.com. 
12. Ukrayins'ka mova: entzyklopediia [The Ukrainian Language: Encyclopedia]: 2-he vyd./ Redkol. : V. M. Rusanivs'kyi, O. O. Taranenko, M. P. Ziabliuk [ta in.]. - K. : Ukr. Entzykl. imeni M. P. Bazhana, 2004. $824 \mathrm{~s}$.

Чумак Л. Н., Сниховская И. Э. Структурно-семантические и функциональные особенности лексических инноваций, выражающих понятие "gепетаtion" в современном англоязычном медийном дискурсе.

Статья посвящена анализу строения, значения и функциональных характеристик лексических единиц в медийном дискурсе, которые употребляются для обозначения понятий, связанньх с принадлежностью людей к различным демографическим поколениям современного англоязычного общества. Фактической базой служат современные лексикографические источники и фрагменты медийного дискурса в он-лайн версии англоязычных газет и журналов. Выражение понятия "generation" лексическими средствами актуализируют репрезентации таких референтов, как: люди по возрастной, групповой принадлежности, статусу, определенным характерным признакам, группы единомышленников и $m . n$.

Ключевые слова: новые лексемы, сочиально-демографические группь, медийный дискурс.

\section{Chumak L. M., Snikhovska I. E. Structural, Semantic and Functional Features of Lexical Innovations Expressing the Notion of "Generation" in Modern English-Language Media Discourse.}

The article is devoted to the analysis of the functional features of the new lexical units referring to the characteristic features of socio-demographic groups, and the consideration of the factors shaping the social sphere of our epoch make it possible to obtain a more accessible and informative view of the language units as a means of expressing and communicating information. The relevance of the chosen topic is determined by the analysis of language phenomena that are correlated with the human factor. The purpose of the paper is to examine the formal and semantic structure of the innovative lexical units conveying the notion of belonging to different demographic generations, as well as to consider the peculiarities of their functioning in modern English-language media discourse.

The current study draws from the idea about the development of the communicative value of the transformed linguistic units taking into account two interrelated tendencies of the integration and differentiation of the language units. The above trends evoke the vocabulary functioning, which in fact accounts for the emergence of new language units. The selection of lexical units to express the notion of "generation" was carried out by the continuous sampling method of the contemporary English-language media discourse, focusing the reader's attention on the ground-breaking social concepts.

It is shown that the use of the analyzed lexical units in the media discourse is associated with the designation of the new phenomena related to a certain generation's representatives that highlight the salient features of their social life. The conclusion is made that contemporary media discourse plays a significant role: it expresses the notion of "generation" by lexical means, explaining the specifics of world perception by various social and age groups, defining their common and distinctive features.

Key words: new lexemes, socio-demographic groups, media discourse. 